\title{
Ethics
}

\section{Relocating the self: The crisis in volunteerism*}

\author{
Neloufer de $\mathrm{Mel}^{1}$ \\ Journal of the Ceylon College of Physicians, 2016, 47, 52-53
}

\section{Introduction}

Thinking of the self, or selfhood, with regard to volunteer work not only raises many interesting questions about how we think about our own selfdevelopment, but also points to a crisis in volunteerism today. On the one hand, the typical image we have of a volunteer is someone who is self-less, and gives of his/her time and labour for the benefit of others. However, many of us have been socialized into volunteerism from an early age, particularly at schools, based on its benefits to both self and community. In this view, the process of volunteering, whether through shramadhanas and environmental cleanups or fund raising drives etc. is about working for, and with others in a manner that enables the development of ethical, civic, social responsibility and personality growth that in the long term, fosters pro-social behaviour. Studies conducted in both the education and psychosocial fields support this view through their findings of how participating in voluntary activities protect against psychosocial risk and brings tangible health benefits to the volunteer. ${ }^{2}$ Looked at this way, the development of both self and community through voluntary work becomes indistinguishable and inseparable from each other.

Historically, voluntary workh as played a major role in the empowerment of individuals who have been excluded in some way. Volunteering activity and membership in volunteer organizations, for instance, were the only acceptable avenues available for $19^{\text {th }}$ century middle class women in both Western and Asian societies to emerge from their homes into the public sphere. Whether from within Ladies' Leagues affiliated to Churches, or Federations of Housewives; or Bhadra and Mahila Samitis, women who had been secluded, educated in their homes, denied access to the paid workforce because of social norms of the time, and married to become mothers at a relatively early

\footnotetext{
*This article draws on my keynote address at the Golden Z Club of the Medical Faculty at its $11^{\text {th }}$ AGM in September 2015, and the District meeting of the Zonta Club, Colombo, January 2016.
${ }^{1}$ Senior Professor and Head, Department of English, University of Colombo.

age, entered the public sphere through their voluntary work. This work taught them how to negotiate with bureaucrats, politicians, medical officers, and education boards dominated by men in order to get their work done.

Through this activity women learnt civic leadership and fundraising skills, electoral processes (electing office bearers of their organizations), and thereby, of representational government. It was not long before this band of women volunteers joined the women's movement and the feminists of the $19^{\text {th }}$ and early $20^{\text {th }}$ centuries to struggle for the universal right to vote, and for the right to women's education. ${ }^{3}$ An important lesson from this $19^{\text {th }}$ century history of women's volunteering, therefore, is of how it not only fostered self-growth amongst the volunteers, but also led to the empower-ment of a critical mass of other women by enabling them access to education, the workforce, the vote and property rights etc. The impact, therefore, of these female volunteers has lasted for more than a century and enabled successive generations of us to follow professions of our choice and lead the lives we do today.

But where is volunteerism today? In today's competitive world, education, subject specializations and the job market define who we want to be. Jon Dean, in a study of volunteering and the market economy, found that young people volunteer today to pick up skills and networks in order to compete in the job market rather than for community development or social equity. His evidence from many admission policies of US universities point to how they look for voluntary work on student applications because university administrators are preoccupied with student employability (a key performance indicator (KPI) for university ranking etc.) which they think would be easier to achieve if the student is already connected to a larger network and has work skills. Dean also writes of what the 'volunteer industry' has become today, where global volunteer organizations have changed recruitment strategies to entice young people on the basis of the benefits of volunteering not so much for the welfare of underprivileged communities, but for enhanced job prospects in a globalized world. ${ }^{4}$ In Sri Lanka, the majority of university entrants are admitted on their Z scores and do not face an interview or analysis of their curriculum vitae. But our universities 
are similarly under pressure to produce employable graduates, and enhancement courses for credit including soft skills and voluntary community activities, while beneficial in and of themselves, are also being mainstreamed to achieve the goal of employability.

This kind of volunteerism with a labour market in mind, is a very different form of volunteerism to that of the late $19^{\text {th }}$ and early $20^{\text {th }}$ century that led to women's collective empowerment. Certainly there were women of that time who also sought personal advancement through their voluntary work. A significant difference however, is that unlike earlier, today's young volunteer who joins a voluntary organization for $\mathrm{CV}$ enhancement does not contribute to fostering a sense of community amongst volunteers as volunteers. Rather, they begin to see everyone else in the group as a possible 'good contact' to have, and calculate the benefits to themselves, with the good work as an additional output. This approach is very different from a commitment to long term volunteering on the basis that, as studies on young adults and volunteering have found, it makes one more extroverted, enjoy greater self-esteem, possess greater self-sufficiency, emotional stability and empathy for others. ${ }^{5}$

Studies have also found evidence that individuals who thought volunteering useful for capacity and skills building that were useful to themselves, stayed in volunteer groups for a shorter period of time than others who were motivated by goals of social equity and justice. ${ }^{6}$ However other studies also found that irrespective of original motivation, if there was good group integration and satisfaction with their voluntary activities, individuals were more likely to stay on in a club or organization, or volunteer in other activities later on in life. In other words even those who joined primarily out of self-interests and to pursue their own develop-ment, acquired a longer-term commitment to volun-teering if they enjoyed the experience. It was also found that young people were more likely to join volunteer organizations if their parents had been volunteers and thereby provided a good role model and support for their children's volunteering activities. ${ }^{8}$

How does one (re)turn volunteerism, then, to a place where the development of self and community are coeval, and enjoy equal status? How does one build that ethos into programming and recruitment drives? How does one work as a group that empowers the marginalized and vulnerable so that they become resilient and sustainable in their own right? How does one make voluntary activity enjoyable in a manner that does not lose sight of its serious goals? These are the challenges that any volunteer group faces in order to be effective and sustainable.

For the above to take place, we have to re-think the place of self in volunteerism. Many accolades, such as the $\mathrm{V}$ Awards, sponsored by the National Steering Committee on Volunteerism and UN Volunteers, held in Sri Lanka in January 2016, have, as their objective the recognition and honoring of individuals who have 'made an extraordinary and self-less contribution to society at large'. ${ }^{9}$ My argument so far has been that volunteering is not about a lack of self. The best kind of volunteering incorporates sustained self-growth that comes from working for the development of as many as possible. An unknown author is quoted as saying: 'Volunteering is the ultimate exercise in democracy. You vote in elections once a year, but when you volunteer, you vote every day about the kind of community you want to live in'. ${ }^{10}$ This is because long term, active volunteers bring back, or reinforce - as the case maybe - humanistic, ethical social values so important for societal change. These values form the bedrock of a society that is caring, collaborative, just, non-violent and therefore healthy. Therefore to all young volunteers, I quote as Mahatma Gandhi famously said, "be the change you wish to see in the world."

\section{References}

1. Marta, Elena, Maura Pozzi, 'Young People and Volunteerism: A Model of Sustained Volunteerism During the Transition to Adulthood,' Adult Development 15, 3546; Post, Stephen G., 2005, 'Altruism, Happiness and Health: It's Good to be Good,' International Journal of Behavioral Medicine 2008; 12: 2, 68.

2. Bojar, Karen, 1998 , Volunteerism and Women's Lives: A Lens for Exploring Conflicts in Contemporary Feminist Thought, Historical Importance and Socioeconomic Value of Women's Contribution as Volunteers, in Kate Conway-Turner, Suzanne Cherrin, Jessica Schiffman, Kathleen Doherty Turkel (eds.), Women's Studies in Transition: In Pursuit of Interdisciplinarity, Newark: University of Delaware Press, 43.

3. Dean, Jon. 'Volunteerism and the Market, People, Place and Policy 2015; 9: 139-48.

4. Marta, Elena, Maura Pozzi, 'Young People and Volunteerism: A Model of Sustained Volunteerism During the Transition to Adulthood. Adult Development 2008; 15: 36.

5. Capanna et al, cited in Marta \& Pozzi, 2008, 36.

6. Marta \& Pozzi, 38.

6. Ibid, 37

8. http://www.vawards.Ik/about/ Accessed 28/1/2016

9. http://www.quotegarden.com/volunteer-apprec.html 